\title{
ПРОБЛЕМНІ АСПЕКТИ РОЗВИТКУ РИНКІВ ЖКП В УКРАЇНІ НА СУЧАСНОМУ ЕТАПІ
}

\author{
Хмєліньска Марта Володимирівна \\ аспірантка \\ ДУ «Інститут регіональних досліджень імені І. М. Долішнього НАН України» (м. Львів,Україна) \\ ORCID ID: 0000-0002-4852-5362 \\ kvasnecjamarta1993@gmail.com
}

В науковій статті досліджено проблемні аспекти розвитку ринків ЖКП в Україні в умовах проведення секторальної реформи. Аналіз проблем проведено в розрізі підсистем ЖКГ. Проведено аналіз стану житлового фонду в Україні за період 2014-2018 роки та визначено проблеми, які виникли в результаті старіння житлового фонду. Здійснено аналіз ефективності економічної діяльності в сфрері надання ЖКП, що дозволило зауважити невідповідність структур і систем управління житлово-комунальними підприємствами умовам та вимогам інтегрування в ринкову економіку. Встановлено, що підприємства сфрери не мають економічних стимулів до зниження надмірних витрат матеріальних і технічних ресурсів та оnтимізації тарифрів щодо надання ЖКП споживачам та обгрунтовано низьку інвестиційну привабливість підприємств сфрери через їх високу фінансову нестабільність.

Ключові слова: житлово-комунальні послуги, ринки ЖКП, житловий фонд, підприємства сфрери ЖКГ, економічна діяльність.

DOI: https://doi.org/10.32845/bsnau.2019.3.4

Постановка проблеми. В умовах сьогодення одним з основних напрямів здійснення соціально-економічних та господарчо-функціональних трансформацій в економічній системі нашої держави $є$ проведення секторальної реформи в ЖКГ України. Стан розвитку сфери сьогодні чітко демонструє накопичення проблем, які є результатом функціонування національного господарства на засадничих принципах адміністративно-командної економіки впродовж періоду незалежності нашої держави. Незважаючи на те, що спроби реформування ЖКГ тривають від початку 90-х рр., суттєвих системних змін та приведення галузі до економічно та інвестиційно привабливого рівня так і не відбулося. Відтак пошук ефективних механізмів регулювання ринків ЖКП вимагає першочергово детального вивчення стану їх розвитку та ефективності надання послуг споживачам.

Аналіз останніх досліджень та публікацій. Дослідженням проблемних аспектів розвитку ринків житлово-комунальних послуг в Україні займаються такі вітчизняні вчені: I. Абрамова, І. Драган, Є. Жмеренко, Н. Захаренко, В. Ляшенок, О. Кирилович, В. Мамонова, С. Мельник, С. Мирза, Г. Онищук, А. Раховська, С. Шульц та інші. Проте, зважаючи на транссормаційні процеси в економіці нашої держави на сучасному етапі вагомим $€$ розгляд та виділення основних проблем розвитку ринків ЖКП в умовах проведення секторальних реформ.

Постановка завдання. Відтак важливим $є$ проведення проблемного аналізу стану ринків ЖКП в Україні в контексті реформування галузі.

Виклад основного матеріалу дослідження. Оскільки ЖКГ можна визначити як складний соціально-економічний комплекс господарських структур, які функціонують для утримання та розвитку житлового фонду і забезпечення комунального обслуговування споживачів ЖКП, в складі системи ЖКГ слід виокремити такі підсистеми: житловий фонд; економічна діяльність 3 надання ЖКП споживачам (населенню і суб'єктам господарюванню) (до таких послуг належать: електро-, газо-, тепло-, водопостачання, водовідведення, обслуговування ліфтового господарства та систем внурішньобудинкових комунікацій); інженерні мережі та об'єкти внутрішньодворового, квартального, поселенського та міжселенського значення (до таких відносяться: теплоенергоцентралі, котельні, споруди оборотного водопостачання, насосні станції першого підйому води та каналізаційні, станції аерації і біологічної очистки стоків тощо); діяльність з благоустрою території та утримання у задовільному експлуатаційному стані житлового фонду, а також нежитлових будівель i споруд, прибудинкових територій, населених пунктів та системи розселення загалом.

Враховуючи те, що функціонування та розвиток ЖКГ покликане забезпечити комфортні та безпечні житлові умови як першочергової потреби суспільства, виникає питання ефективності формування та розвитку, обслуговування житлового фонду.

Чинний станом на 2018 рік житловий фонд налічуе 9137304 будинків різних форм власності. Управління сферою ЖКГ адміністративно-територіального формування та контроль за його ефрективністю здійснюють виконавчі органи місцевих рад. До їх повноважень сьогодні віднесені питання формування регламенту роботи і умов технічного та санітарного утримання, а також розвитку комунальних підприємств, житлового фонду на території громади та споруд благоустрою, розробка проектів планування та забудови території, розподіл та контроль за використанням земель.

В умовах проходження реформи в напрямку децентралізації в Україні комунальні підприємства території міст та селищ підпорядковані безпосередньо місцевим радам, їх доходи виступають джерелом поповнення місцевих бюджетів, а покриття збитків забезпечується також з відповідних бюджетів. За ефективність управління та дотримання норм експлуатації житлового фонду відповідальність несуть підприємства та організації, підпорядковані органам місцевого самоврядування, відповідним відомствам або приватним підприємствам.

Проведення аналізу стану житлового фонду в Україні в період 2014-2018 рр. дозволяє зауважити повільні темпи його збільшення та зростання площі, яка припадає на одну особу населення (23,7 кв. м.). При цьому, сьогодні доцільним $€$ покращення стану житлового фонду та системи управління ним. 3 кожним роком підвищується зношеність житлового фонду: 45539 житлових будинки сьогодні віднесені до ветхого

Вісник Сумського національного аграрного університету 
житлового фонду (цей показник при порівнянні 2018 та 2014 pp. зріс на 3,7\%), 16799 житлових будинки знаходяться в аварійному стані (зростання у 2018 році в порівнянні з 2014 роком складає 9,0\%). Найбільша питома вага ветхого житло- вого фонду в Одеській (1,06\%), Сумській $(1,02 \%)$ та Житомирській $(0,85 \%)$ областях; найменша - в Кіровоградській $(0,03 \%)$, Чернівецькій $(0,07 \%)$ та Закарпатській $(0,12 \%)$ областях (рис. 1).

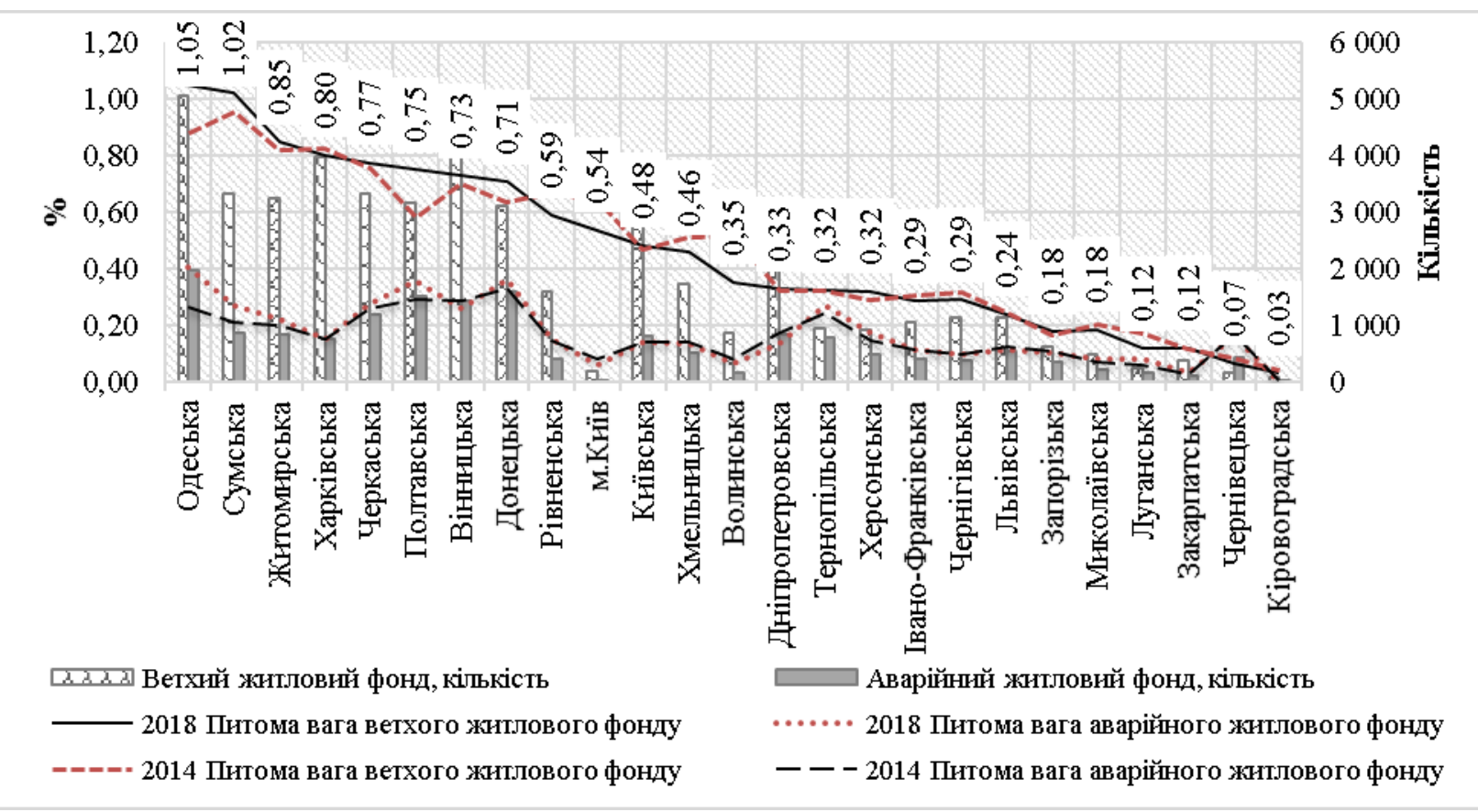

Рис. 1. Наявність ветхого та аварійного житлового фонду в регіонах України, 2014-2018 рр.

Джерело: на основі даних Державної служби статистики України

Більшість житла в Україні була зведена в період 6080-х рр. (рис. 2) як тимчасове з терміном експлуатації 30-50 років. Таким житлом користується сьогодні близько 57,5\% домогосподарств у містах України. При цьому, в 44,8\% домогосподарствах капітальний ремонт не проводився, до 1990 р. його було проведено у 5,2\% домогосподарств, 11,6 - у період 1991-2000 рр., 38,4\% після 2001 року. Враховуючи те, що 3 часу будівництва будинків у 60-х роках минуло більше 50-ти років, можна говорити про підвищену загрозу безпеці життя і здоров'я мешканців.

Таким чином, будинки, які були зведені у першу чергу будівництва в 60-х роках, мали б підлягати зносу у 2017 році. Враховуючи те, що багато з таких будинків жодного разу капітально не ремонтували, вони мали б іти під знесення ще десять років тому. Впродовж періоду незалежності України більшість житлового фонду управляються ЖЕКами, які, по-перше, не мають чітко визначеного законодавством обов'язку проведення модернізації будівель, по-друге, не отримують ві- дповідного і достатнього фінансування на реалізації цього завдання. Враховуючи, що більшість постачальників комунальних послуг є підприємствами комунальної форми власності, відповідальність за належний рівень надання ЖКП покладається на територіальні громади. Крім того, відповідно до п. 7 статті 10 Закону України «Про приватизацію державного житлового фонду», колишні власники, які володіли багатоквартирними будинками до моменту приватизації, зобов'язані брати участь у фінансуванні їх ремонту та сприяти організації його проведення. Оскільки такими «колишніми власниками» знову ж таки є територіальні громади, саме на органи місцевого самоврядування покладається зобов'язання забезпечити фінансування капітального ремонту будинків згідно з прийнятими місцевими програмами. При цьому, ситуація з фінансовою спроможністю місцевих бюджетів до реалізації поставленого завдання на своїй території в період незалежності не сприяла його реалізації, оскільки в бюджетах не було коштів. 


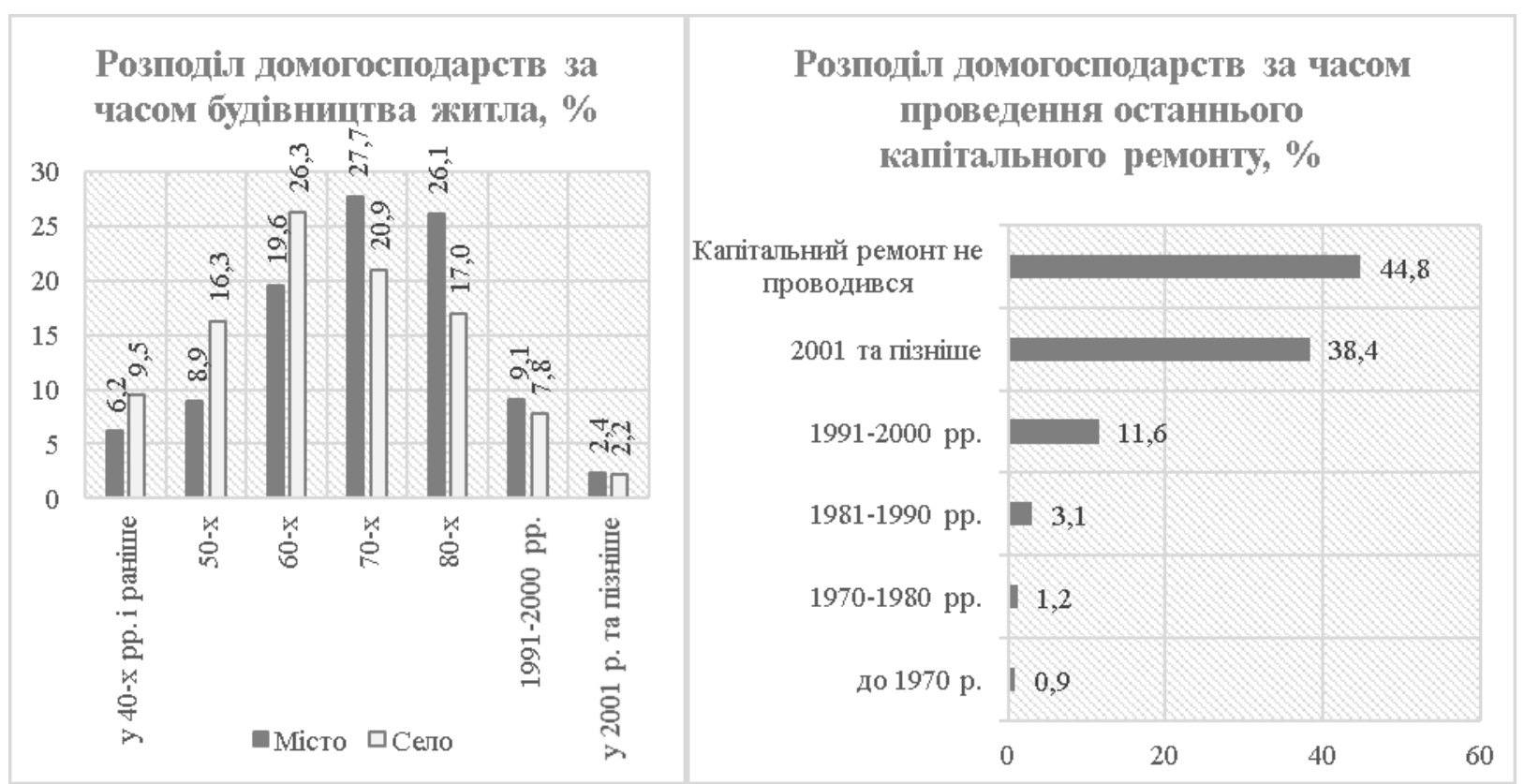

Рис. 2. Розподіл домогосподарств за часом будівництва житла та проведенням капітального ремонту, \%

Джерело: на основі даних Державної служби статистики України

Відтак, ситуація старіння житлового фонду на сьогоднішній день $€$ однією $з$ найбільш гострою в Україні і вимагає грунтовного чіткого цілеорієнтованого і ефрективного підходу до подолання цієї проблеми на загальнодержавному рівні. Фізичне і моральне старіння внутрішніх систем і кострукцій житлових будівель, попри небезпеку для життя і здоров'я людей та зниження комфортності їх життєдіяльності, має вплив і на зниження якості ЖКП. Окрім того, незадовільний стан внутрішньобудинкових систем та низький рівень теплозахисних властивостей конструкцій веде високих показників споживання тепла, газу, електроенергії та води. Так, згідно проведеної Міністерством розвитку громад та територій України оцінки втрат газу при споживанні теплової енергії цей показник складає 65\% (50\% втрат є наслідком поганого отеплення будівель, 15\% - відсутності регулювання тепла), що дорівнюе приблизно 1,8 млрд дол. США щорічно [5]. Застарілою $є$ більша частина системи виробництва і транспортування теплової енергії в Україні; а це результується $30 \%$ втрати теплової енергії. 18\% усіх котлів, які виробляють теплову енергію мають термін експлуатації більше $20 \%$, а більше $20 \%$ теплових мереж знаходяться в аварійному стані та потребують заміни [5].

3 іншої сторони, попри високі показники приватизації житла (93,7\% [3]), існує проблема організації обслуговування й експлуатації житлових будинків. Як зауважує Г. Онищук, велика кількість дрібних власників, вимоги соціального захисту населення та обумовленість об'єктивними причинами неліквідності неподільного майна загального користування в житловому господарстві $€$ стримуючими важелями для залучення зовнішніх фінансових ресурсів і не дозволяють використовувати механізм майнових гарантій повернення банківських кредитів та забезпечення економічних інтересів інвесторів [4].

Критичною є ситуація і в питанні стану ліфтового господарства в Україні. За даними Міністерства розвитку громад та територій України, в нашій країні налічується більше 27 тисяч багатоповерхових житлових будинків, в яких налічується більше 86 тисяч ліфтів. 3 них 55 тис. ліфтів експлуатуються станом на початок 2019 року більше 25 років. Таким чином, такими є 63,5\% ліфтів в Україні, а близько 1,5\% від загальної кількості ліфтів є непрацюючими. Поширеність цієї проблеми по регіонах неоднакова. Так, найбільше ліфтів, які експлуатуються понад 25 років, у Луганській (98\%), Херсонській $(95 \%)$ та Кіровоградській (88\%) областях. Натомість найменшим $€$ цей показник у м. Києві - 46\% [5].

Аналіз ефективності економічної діяльності в ссрері надання ЖКП дозволяє зауважити невідповідність структур і систем управління житлово-комунальними підприємствами умовам та вимогам інтегрування в ринкову економіку. Підприємства цієї сфери не мають економічних стимулів до зниження надмірних витрат матеріальних і технічних ресурсів та оптимізації тарифів щодо надання ЖКП споживачам. Негативно на їх розвиток впливає також відсутність інвестицій та недосконалість механізмів забезпечення гарантій в умовах залучення позикового капіталу, а також те, що фінансово-кредитні установи не розглядають сферу ЖКГ як інвестиційнопривабливу через високу фінансову нестабільність суб'єктів господарювання, які її представляють.

Основними ознаками низької ефеективності функціонування та розвитку підприємств ЖКГ є: відсутність поступу в напрямі зменшення ресурсних витрат та досягнення високого рівня ефективності використання ресурсів; низька якість обслуговування споживачів ЖКП; неефективність кадрової політики підприємств, що проявляється у низьких показниках продуктивності працівників; відсутність інвестиційної діяльності в сфрері; недосконала тарифна політика.

Станом на 1 січня 2019 року ринок надавачів ЖКП на 50\% складається з підприємств житлового господарства, $22 \%$ - підприємств водопостачання та водовідведення, $15 \%$ - підприємств у сфрері поводження з побутовими відходами та 13\% - підприємств теплопостачання. Серед підприємств теплоенергетики (ТKЕ) та водоканалізаційного господарства понад 90\% перебувають у комунальній власності [5].

Фінансові проблеми підприємств ЖКГ впродовж останніх років лише посилюються (рис. 3). Вираженим проявом кризовості розвитку галузі $є$ її збитковість. Так, аналіз 
динаміки збитків підприємств ЖКГ за останні п'ять років засвідчує зростання цього показника у 2018 році у порівнянні з 2014 роком вдвічі, з 3,0 млрд грн. до 6,2 млрд грн. Натомість прибутки підприємств сфери коливаються в межах до 1 млрд. грн., тобто $€$ значно нижчими.

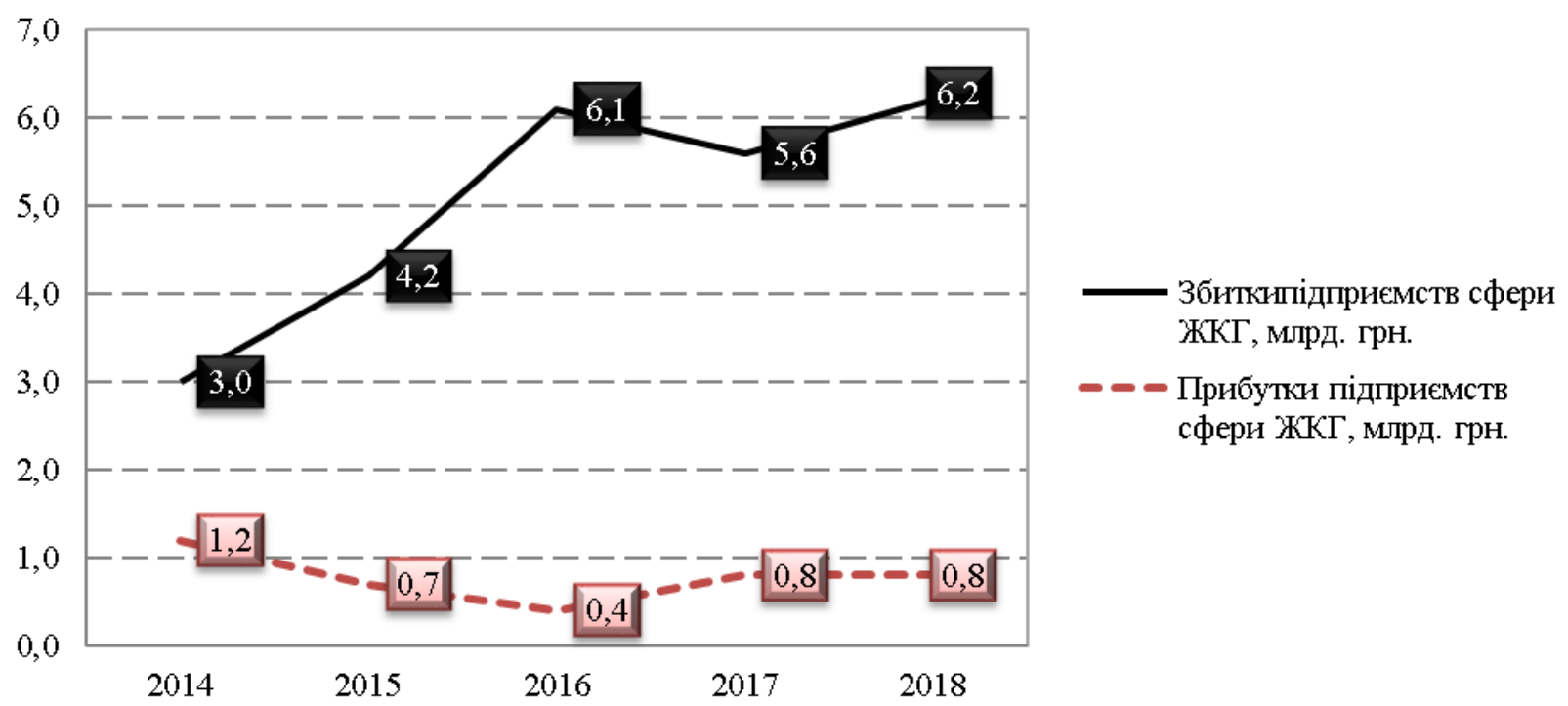

Джерело: на основі даних [7]

Рис. 3. Динаміка фінансових результатів підприємств ЖКг України, 2014-2018 рр.

Таким чином, обсяг збитків підприємств ЖКГ за 2018 у 8 разів більший за обсяг прибутків за цей період, що свідчить про глибоку кризу розвитку галузі.

Найбільш збитковими у 2018 році були підприємства Донецької області (1420,3 млн. грн.), м. Києва (1015,1 млн. грн.), Дніпропетровської (690,4 млн. грн.) та Львівської $(538,4$ млн. грн.) областей, найнижчими показниками збитковості характеризувалися підприємства Закарпатської (19,5 млн. грн.), Сумської (28,9 млн. грн.), Волинської (30,9 млн. грн.) та Тер-

нопільської (36,0 млн. грн.) областей. Тобто підприємства чотирьох регіонів з найбільшими обсягами збитків складають $59,1 \%$ від загального розміру збитків. Натомість найвищими прибутками характеризувалися суб'єкти господарювання сфери ЖКГ м. Києва (318,8 млн. грн.), Харківської (46,5 млн. грн.), Черкаської (46,4млн. грн.), Київської (41,0 млн. грн.) та Чернігівської (40,9 млн. грн.) областей.

Якщо провести аналіз рівня збитковості підприємств ЖКГ за підгалузями (рис. 4), можна зробити такий висновок:

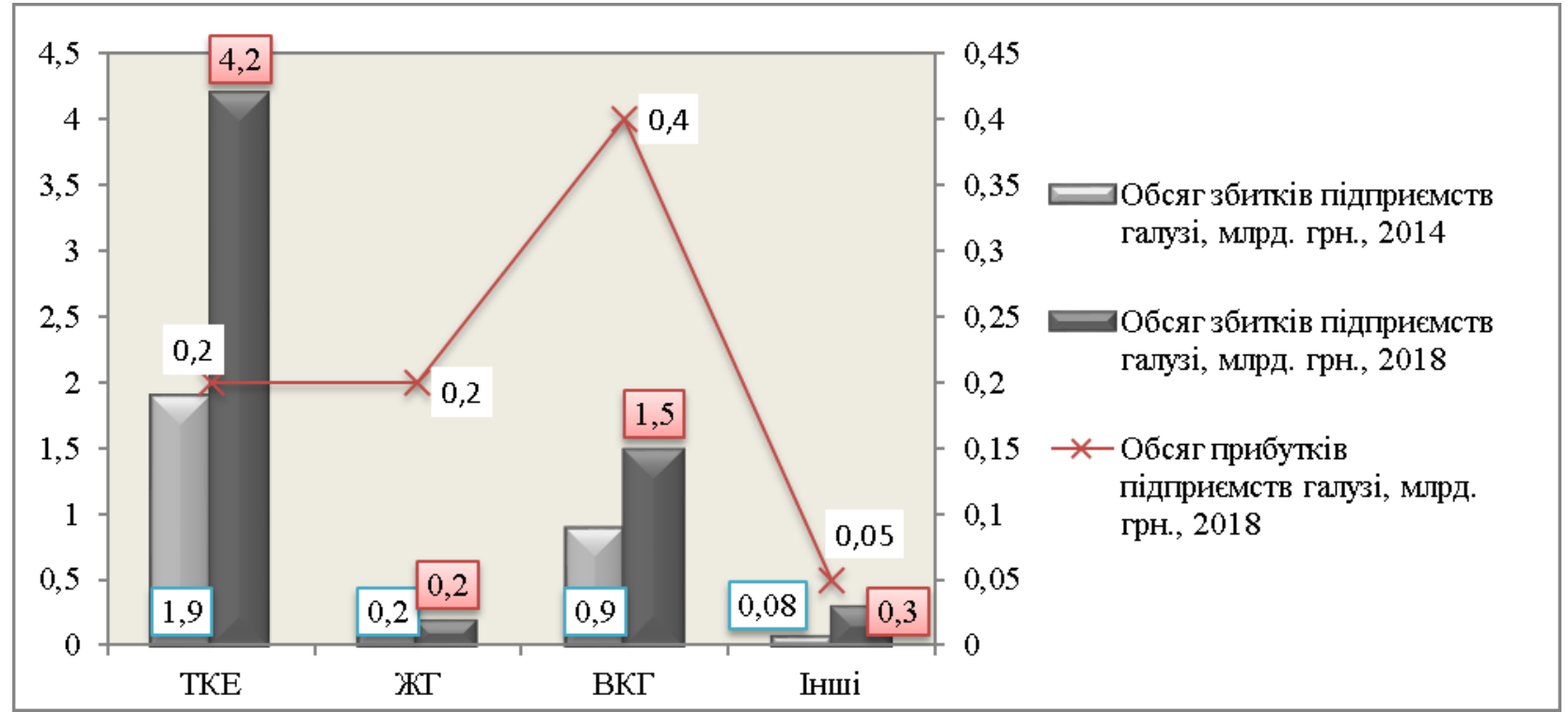

Рис. 4. Фінансові результати від звичайної діяльності до оподаткування підприємств ЖКГ в розрізі підгалузей, 2014, 2018 рр.

Джерело: на основі даних [5]

1) найбільш збитковими є підприємства комунальної теплоенергетики (ТКЕ) - збитки цих підприємств склали у 2018 році 4,2 млрд. грн., що становить 67,7\% збитків підприємств галузі; при порівнянні рівня збитковості підприємств
TKE у 2018 та 2014 рр. помітно стрімке зростання рівня збитковості - у 2,2 рази;

2) підприємства водно-каналізаційного господарства (ВКГ) також характеризуються зростанням збитковості у 
2018 році в порівнянні з 2014 роком - в 1,7 разів (1,5 млрд. грн.);

3) щодо прибутковості підприємств ЖКГ, найбільшими обсягами прибутків характеризується підприємства ВКГ (0,4 млрд. грн.), суб'єкти господарювання ТКЕ і ЖГ мають прибутки на рівні 0,2 млрд. грн.

За аналізований період суттєво посилилася проблема накопичення дебіторської та кредиторської заборгованості. Якщо у 2014 році сума дебіторської заборгованості складала 12,9 млрд. грн., то у 2017 р. - 23,7 млрд. грн., а у 2018 р. 30,3 млрд. грн., тобто відбулося зростання показника на 234,9\%. В розрізі підгалузей ЖКГ 66\% заборгованості характерні для ТКЕ, 16\% - для ВГК, 16\% - для житлового господарства і 2\% - для інших підприємств. При порівнянні показників 2018 та 2014 рр. помітним є зменшення частки дебіторської заборгованості у підприємств ТКЕ на 10 в.п. та ВГК на 1 в.п. Натомість видно суттєве зростання питомої ваги дебіторської заборгованості підприємств житлового господарства (на 2,8 в.п.).

У структурі дебіторської заборгованості підприємств ЖКГ переважну частину складає заборгованість населення за спожиті ЖКП (у 2018 році часка заборгованості населення склала $81 \%$ суми дебіторської заборгованості).

Аналіз динаміки заборгованості населення з оплати ЖКП в Україні за період 2014-2018рр. (табл. 1) дозволив зауважити нерівномірність розподілу несплати платежів за регіонами. Так, до регіонів з найвищими обсягами заборгованості населення за ЖКП відносяться м. Київ (5081 млн. грн.), Дніпропетровська (4002 млн. грн.), Харківська (3520 млн. грн.) та Донецька (1942 млн. грн.) області, тобто регіони з найбільшою чисельністю жителів; з найнижчими - Чернівецька (118 млн. грн.), Волинська (145 млн. грн.) та Тернопільська (171 млн. грн.) області.

\section{Динаміка обсягів заборгованості населення з оплати ЖКП в Україні за період 2014-2018 рр.}

Таблиця 1

\begin{tabular}{|l|c|c|c|c|c|c|}
\hline \multicolumn{1}{|c|}{ Область } & $\mathbf{2 0 1 4}$ & $\mathbf{2 0 1 5}$ & $\mathbf{2 0 1 6}$ & $\mathbf{2 0 1 7}$ & $\mathbf{2 0 1 8}$ & Темп приросту, 2018/2014, \% \\
\hline Вінницька & 96 & 85 & 110 & 140 & 259 & 270,0 \\
\hline Волинська & 75 & 76 & 43 & 55 & 145 & 193,7 \\
\hline Дніпропетровська & 1948 & 2186 & 2645 & 2822 & 4002 & 205,5 \\
\hline Донецька & 905 & 1133 & 1287 & 1365 & 1942 & 214,6 \\
\hline Житомирська & 138 & 146 & 179 & 189 & 339 & 245,9 \\
\hline Закарпатська & 121 & 128 & 123 & 139 & 169 & 139,8 \\
\hline Запорізька & 643 & 725 & 868 & 924 & 1525 & 237,2 \\
\hline Івано-Франківська & 108 & 115 & 119 & 147 & 232 & 214,9 \\
\hline Київська & 345 & 370 & 451 & 565 & 839 & 243,3 \\
\hline Кіровоградська & 123 & 120 & 110 & 132 & 279 & 226,5 \\
\hline Луганська & 269 & 345 & 404 & 435 & 633 & 235,1 \\
\hline Львівська & 366 & 269 & 261 & 373 & 666 & 182,0 \\
\hline Миколаївська & 198 & 202 & 261 & 268 & 441 & 222,5 \\
\hline Одеська & 564 & 603 & 832 & 914 & 1161 & 205,8 \\
\hline Полтавська & 275 & 283 & 386 & 374 & 687 & 249,6 \\
\hline Рівненська & 144 & 152 & 75 & 106 & 272 & 188,5 \\
\hline Сумська & 207 & 169 & 154 & 241 & 439 & 212,0 \\
\hline Тернопільська & 62 & 63 & 77 & 74 & 171 & 275,6 \\
\hline Харківська & 1369 & 1428 & 1738 & 2406 & 3520 & 257,1 \\
\hline Херсонська & 186 & 219 & 250 & 256 & 417 & 224,4 \\
\hline Хмельницька & 95 & 81 & 73 & 113 & 274 & 288,4 \\
\hline Черкаська & 200 & 212 & 234 & 252 & 443 & 21,3 \\
\hline Чернівецька & 45 & 46 & 77 & 63 & 118 & 261,6 \\
\hline Чернігівська & 113 & 89 & 70 & 138 & 304 & 269,2 \\
\hline м. Київ & 1543 & 1732 & 2907 & 3908 & 5081 & 329,3 \\
\hline Україна & 10138 & 10977 & 13734 & 16395 & $\mathbf{2 4 3 5 7}$ & $\mathbf{2 4 0 , 3}$ \\
\hline
\end{tabular}

Джерело: сфрормовано за даними: [5]

Темп зростання обсягів заборгованості в середньому по Україні у 2018 році в порівнянні з 2014 роком складає 240,3\%. Найбільше зросла заборгованість за оплату ЖКП у м. Києві (329,3\%), найменше - у Закарпатській області $(139,8 \%)$.

Відбулося суттєве зростання і кредиторської заборгованості підприємств ЖКГ. У 2018 році вона становила 38,4 млрд. грн., що на 25\% більше, ніж у 2017 році (30,6 млрд. грн.), і на 120,7\% у порівнянні з 2014 роком. У структурі кредиторської заборгованості підприємств ЖКГ основну частину займає заборгованість за спожитий природний газ та електроенергію (88\% від загальної суми кредиторської заборгованості).
Таким чином, аналіз результатів фінансової діяльності підприємств ЖКГ в Україні впродовж останніх п'яти років засвідчує наявність довготривалої і системної кризи, яка охопила усі підгалузі та несе загрозу фрінансовій безпеці галузі і країни загалом.

Окремим аспектом дослідження виступає аналіз структури заборгованості підприємств за підгалузями (рис. 5).

Борг за спожитий газ станом на 1 січня 2019 року складав 35,9 млрд. грн., за спожиту електроенергію - 6,0 млрд. грн. Як видно, найбільші обсяги несплати за спожитий ресурс у населення (52\% від суми боргу підприємствам ВКГ та $46 \%$ - підприємствам ТКЕ). Борг бюджетних установ в обох випадках незначний: 0,5\% від суми боргу за спожиту електроенергію та 2\% - за газ; борг комерційних споживачів складає 4\% 
за газ та 4,5\% - за електроенергію. Заборгованість з різниці в тарифах на теплову енергію, послуги з централізованого опалення, постачання гарячої води, що утворилася протягом 2016-2018 рр. становить 16,8 млрд. грн. А заборгованість 3 різниці в тарифах на послуги з централізованого водопостачання та водовідведення, постачання холодної води та водовідведення, що утворилася протягом 2016-2018 рр. становить 2,75 млрд. грн.

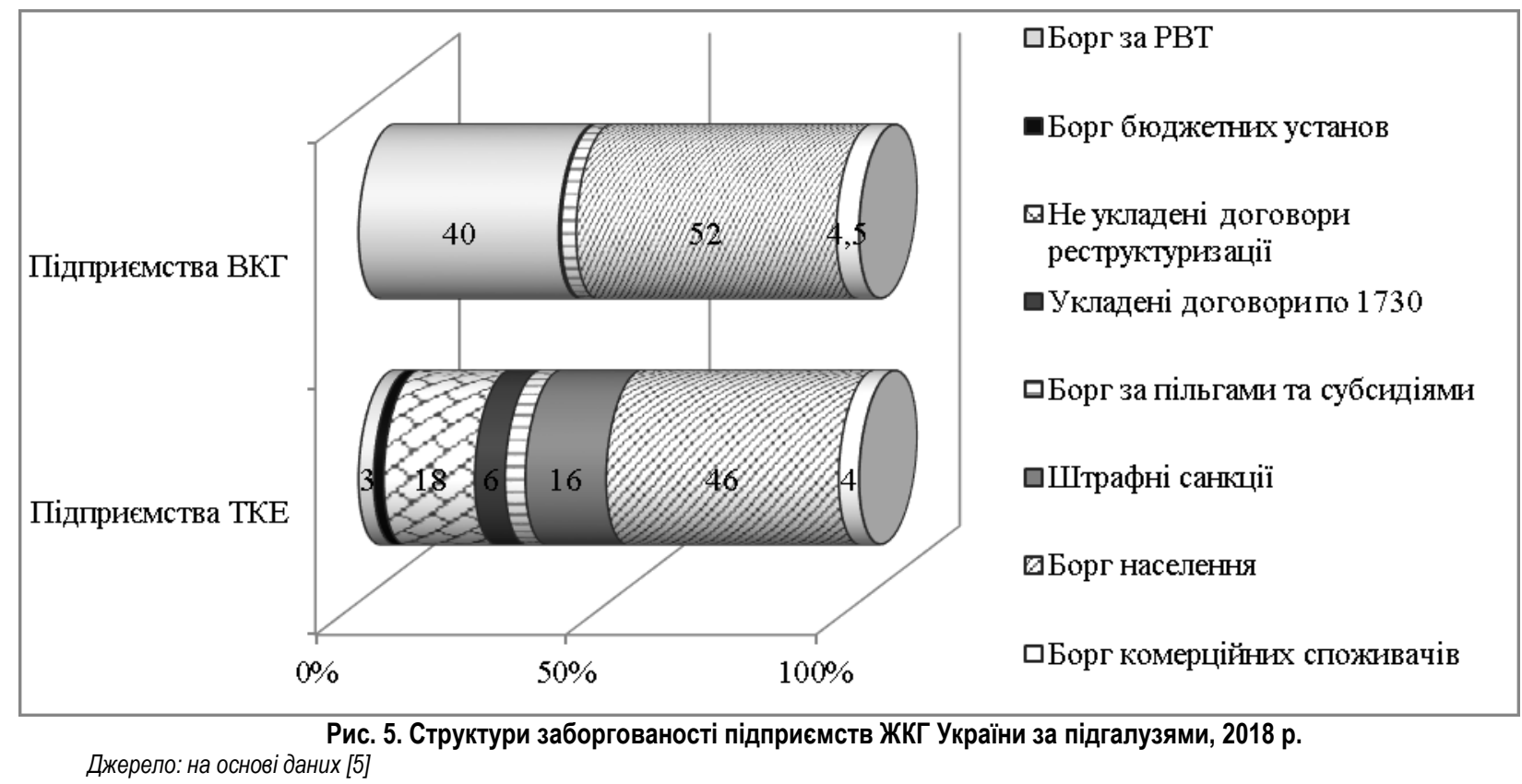

Проведений аналіз дозволяє констатувати, що однією з причин ситуації, що склалася, $€$ неефективна тарифна політика. Незважаючи на те, що Кабінетом Міністрів України затверджено постанову «Про забезпечення єдиного підходу до формування тарифрів на житлово-комунальні послуги» (відповідно до даного нормативно-правового акту в Україні запроваджено механізм розрахунку економічно обґрунтованих тарифрів на ЖКП), нова політика в сфері встановлення економічно обгрунтованих тарифів не може забезпечити відповідну норму прибутку для підприємств ЖКГ та їх належного функціонування. Окрім того, вже сьогодні встановлені тарифи є надто обтяжливими для переважної більшості населення України.

Таким чином, негативні фінансові результати діяльності підприємств ЖКГ впливають і на можливості їх розвитку та модернізації, звужуючи спроможність оновлення матеріально-технічної бази, фрінансування поточних потреб та не сприяють своєчасній виплаті заробітної плати та сплати податків і обов'язкових платежів до державного бюджету. Така ситуація може результуватися не тільки погіршенням вже нестійкого фінансового становища суб'єктів господарювання представників сфери ЖКГ, а й якості ЖКП, що безпосередньо відіб'ється на добробуті і життєдіяльності населення. В результаті відбувається зростання невдоволення та посилення соціальної напруги у суспільстві. «Подальший розвиток підприємств ЖКГ... має бути зорієнтованим на потреби людини, а тарифна політика - на її фінансові можливості» [1].

Висновки. Отже, до основних чинників стримування розвитку ЖКГ в Україні відносяться такі:
- недостатність бюджетного фрінансування ремонту житлового фонду та його застарілість;

- неефективність системи управління підприємствами ЖКГ;

- нерозвиненість ринкових інститутів в сфері, що не сприяє підприємницькій активності в ссрері та її розвитку на засадах конкуренції;

- недосконалість бюджетного фрінансування сфрери, проблеми ефективності та дотримання принципів соціальної справедливості і відкритості в контексті надання субсидій населенню та відшкодування пільг;

- низький рівень платоспроможності населення при споживанні ЖКП

- технічних знос і технологічна відсталість підприємств ЖКГ, що супроводжується обмеженими можливостями надавати якісні ЖКП та неефективністю використання обмежених дороговартісних ресурсів;

- відсутність нормативного визначення системи зв'язків між суб'єктами ринку ЖКП (між виробниками, постачальниками і виконавцями ЖКП); зокрема ця проблема характерна в контексті обслуговування внутрішньо будинкових інженерних мереж.

Подолання перелічених проблем можливе за рахунок удосконалення підходів до проведення реформи у сфері надання ЖКП та її реалізація на засадах та у повній відповідності до загальнодержавних пріоритетів розвитку, забезпечення ефективності механізмів бюджетного фінансування галузі та залучення до фінансування галузі позабюджетних коштів (міжнародних фрінансових організацій та установ).

\section{Список використаної літератури:}

1. Абрамова І. В., Кирилович О. Ф. Аналітична оцінка фінансових результатів діяльності підприємств житлово-комунального господарства. Наукові горизонти, 2019, № 9 (82). С. 13-19.

2. Аналіз фінансово-економічного стану підприємств галузі. Підсумки роботи за 2018 рік. Департамент економіки систем життєзабезпечення Мінрегіону. Міністерство регіонального розвитку, будівництва та житлово-комунального господарства 
України. 13.02.2019 р. 28 с.

3. Захаренко Н. С. Аналіз стану та перспективи розвитку житлово-комунального господарства України. Theoretical and Practical Aspects of Economics and Intellectual Property, 2017. № 15. C. 188-194.

4. Онищук Г. Економіка житлово-комунального господарства: нові підходи у формуванні цінової і тарифної політики. Економіка України. 2001. № 7. С. 22-28.

5. Офріційний сайт Міністерства розвитку громад та територій України. URL: http://www.minregion.gov.ua (дата звернення: листопад 2019 р.).

\section{References:}

1. Abramova, I. V. and Kyrylovych, O. F. (2019), "Analytical estimation of financial results of activity of the enterprises of housing and communal services", Naukovi horyzonty, vol. 9, pp. 13-19.

2. The official site of Ministry of Regional Development, Construction and Housing and Communal Services of Ukraine (2019), "Analysis of financial and economic state of the enterprises of the branch. Results of work for 2018", p. 28.

3. Zakharenko, N. S. (2017), "Analysis of the state and prospects of development of housing and communal services of Ukraine", Theoretical and Practical Aspects of Economics and Intellectual Property, vol. 15, pp. 188-194.

4. Onyshchuk, H. (2001), "Economics of housing and communal services: new approaches in pricing and tariff policy formation”, Ekonomika Ukrainy, vol. 7, pp. 22-28.

5. Economics of housing and communal services: new approaches in pricing and tariff policy formation (2019), available at: http://www.minregion.gov.ua (Accessed November 2019).

Khmielinska Marta, postgraduate, State institution «Institute of regional research named after M. I. Dolishniy of the NAS of Ukraine» (Lviv, Ukraine)

Problematic aspects of the development of the housing and utilities markets in ukraine at the present stage

The scientific article investigates the problematic aspects of the development of housing and communal services markets in Ukraine, which resulted from the functioning of the national economy on the basic principles of administrative and command economy during the period of independence and resulted in the need for sectoral reform. Problem analysis was performed in the context of subsystems of housing and utilities. The analysis of the state of the housing stock in Ukraine for the period 2014-2018 was conducted and the problems that arose as a result of the aging of the housing stock were identified. The analysis of the efficiency of economic activity in the sphere of housing and communal services was provided, which made it possible to note the inconsistency of the structures and systems of management of housing and communal enterprises with the conditions and requirements of integration into the market economy. It is established that the enterprises of the sector do not have economic incentives to reduce the excessive costs of material and technical resources and optimize tariffs for the provision of utility services to consumers, and the low investment attractiveness of the enterprises of the sector due to their high financial instability. The main features of low efficiency of operation and development of utilities include: lack of progress towards reducing resource costs and achieving a high level of resource efficiency; poor quality of service to consumers of utility services; inefficiency of the personnel policy of enterprises, which is manifested in low rates of productivity of employees; lack of investment activity in the field; imperfection of tariff policy. The results of financial activity and accounts payable and receivable of the enterprises of the branch are analyzed. It is established that insufficient budget financing for housing repair and its obsolescence are among the main factors in the development of housing and communal services in Ukraine; inefficiency of the system of management of utilities; underdevelopment of market institutions; imperfection of budget financing of the sphere, problems of efficiency and observance of the principles of social justice and openness in the context of providing subsidies to the population and reimbursement of benefits; low level of solvency of the population when consuming utility services; technical deterioration and technological backwardness of utilities; lack of regulatory definition of the system of relations between the entities of the utility market. activity.

Key words: housing and communal services, housing and communal services markets, housing stock, utilities, economic

Дата надходження до редакції: 11.08.2019 р. 